\title{
Bioencapsulation and Colonization Characteristics of Lactococcus lactis subsp. lactis CF4MRS inArtemia franciscana: a Biological Approach for the Control of Edwardsiellosis in Larviculture
}

\author{
Jiun Yan Loh ${ }^{1,2} \&$ Gemma L. Kay ${ }^{3} \&$ Adeline Su Yien Ting ${ }^{2}$
}

\begin{abstract}
Predominance of beneficial bacteria helps to establish a healthy microbiota in fish gastrointestinal system and thus to reduce emerging pathogen. In this study, the colonization efficacy of Lactococcus lactis subsp. lactis CF4MRS in Artemia franciscana and its potential as a probiotic in suppressing Edwardsiella sp. infection were investigated in vivo. The colonization extent of the bioencapsulated L. lactis was established through visualization of gfp gene-transformed L. lactis in A. franciscana. Here, we demonstrate that when A. franciscana is administrated with L. lactis at $10^{8} \mathrm{CFU} \mathrm{mL}^{-1}$ for $8 \mathrm{~h}$, the highest relative percentage of survival (RPS = 50.0) is observed after inoculation with Edwardsiella sp. The total counts of L. lactis entrapped in Artemia were the highest (ranged from 3.2 to $5.1 \times 10^{8} \mathrm{CFU} \mathrm{mL}^{-1}$ ), when $10^{8}-10^{9} \mathrm{CFU} \mathrm{mL}^{-1}$ of L. lactis was used as starting inoculum, with the bioencapsulation performed within 8-24 h. Fluorescent microscopy showed $g f p$-transformed L. lactis colonized the external trunk surfaces, mid-gut and locomotion antennules of the A. franciscana nauplii. These illustrations elucidate the efficiency of colonization of L. lactis in the gastrointestinal tract and on the body surfaces of Artemia. In conclusion, L. lactis subsp. lactis CF4MRS shows a good efficacy of colonization in Artemia and has the potential for biocontrol/probiotic activity against Edwardsiella sp. infection.
\end{abstract}

Keywords Artemia franciscana $\cdot$ Biocontrol $\cdot$ Edwardsiella sp. · Green fluorescent protein · Lactococcus lactis subsp. lactis

\section{Introduction}

Aquaculture is the fastest growing food industry (Saravanan et al. 2013). However, the rapid expansion of the industry has resulted in massive occurrence of various fish diseases.

$*$ Jiun Yan Loh lohjy@ucsiuniversity.edu.my

\footnotetext{
${ }^{1}$ Faculty of Applied Sciences, UCSI University, No. 1, Jalan Menara Gading, UCSI Heights, Cheras, 56000 Kuala Lumpur, Malaysia

${ }^{2}$ School of Science, Monash University Malaysia, Jalan Lagoon Selatan, 47500 Bandar Sunway, Selangor, Malaysia

${ }^{3}$ Medical Microbiology Research Laboratory, Norwich Medical School, University of East Anglia, Norwich NR4 7UQ, UK
}

Aquaculture of fish, in particularly, turbot Scophthalmus maximus, Japanese flounder Paralichthys olivaceus, Nile tilapia Oreochromis niloticus and catfish Clarias batrachus, often develop diseases such as edwardsiellosis (Sahoo et al. 1998; Kim et al. 2003; Zheng et al. 2004; Padros et al. 2006). The Gram-negative pathogen Edwardsiella sp. is the major cause of edwardsiellosis, which can cause hemorrhagic septicemia including lesions on the skin, muscles and internal organs in many aquatic species (Bullock and Herman 1985; Mohanty and Sahoo 2007). The spread of Edwardsiella sp. in fish culture systems can be transmitted via contaminated equipment and facilities used in cultivation, or during the harvesting process of the live feed (Mainous et al. 2010). Common live feed include Artemia and rotifers and are often used as natural food sources for post-larvae in finfish or shrimp hatchery. Studies showed that Artemia could be a potential bio-vehicle for the transmission of several fish diseases; evidence indicates these live feeds can be involved (directly or indirectly) in transmitting piscine cryptosporidiosis infection caused by Cryptosporidium molnari and Cryptosporidium scophthalmi (Méndez-Hermida et al. 
2007). Sivakumar et al. (2009) claimed that Artemia might be a possible horizontal transmission pathway for Hepatopancreatic parvo-like virus (HPV) in post-larvae of Penaeus monodon (Sivakumar et al. 2009). More importantly, a recent study demonstrated E. tarda and

E. ictaluri can be transmitted via the oral route, particularly when pathogen-infected Artemia was used as a food source for Nile tilapia Oreochromis niloticus larvae (Situmorang et al. 2014). To control edwardsiellosis, conventional chemotherapeutic approaches are carried out, including predisinfection of the facility and application of prophylactic antibiotics for preventative measures or treatment purposes. However, the excessive use of antibiotics raises many food safety concerns; therefore, probiotics would be an advantageous alternative to control Edwardsiella sp. infections.

Probiotics are defined as live microorganisms which, when administrated in adequate amounts, confer health benefits to the host (FAO and WHO 2001). In most cases, probiotics are supplied as live supplements in feed complex, which can then benefit the fish and shrimp through inhibition of pathogenic microbes, improving immune response, improving survival and growth rates, increasing feed utilization, enhancing digestion and promoting antimutagenic or anticarcinogenic activity, and furthermore, some species have been suggested for improvement of water quality in aquaculture systems (Harikrishnan et al. 2010; Andani et al. 2012). In hatchery production, probiotics are generally applied through the oral route through live feed (e.g. Artemia and rotifers) (Hai et al. 2010). Probiotics could help to prevent bacterial infections by preventing the colonization of pathogenic bacteria (Villamil et al. 2010). Effective probiotics used in the fish industry possess several characteristics, including antimicrobial properties, adhesion capacity and growth on the intestinal or external mucous of the fish, are also relatively important to determine the feasibility of the putative probiotic in the field. Chang and Liu (2002) reported only certain bacterial species that colonized the GI tract could exert the protection to the eel Anguilla anguilla $\mathrm{L}$. from edwardsiellosis infection. Thus, probiotic colonization in the GI (gastrointestinal) tract should be of particular importance to determine the viability and functionality of the beneficial bacteria.

In the present study, a potential probiotic strain, Lactococcus lactis subsp. lactis (CF4MRS), previously isolated from farmed fish (Loh et al. 2014; Loh and Ting 2016) was used to evaluate for inhibitory effect against Edwardsiella sp. using A. franciscana as a host in an in vivo pathogenic assays. The bacterial uptake, proliferation and colonization were determined through the employment of $g f p$-transformed L. lactis in the live feed. Efficacy of the bioencapsulation process and the probiotic dosage were also optimized in this study.
Materials and Methods

\section{BacterialCulture of Lactococcuslactissubsp.lactis}

The bacterium Lactococcus lactis subsp. lactis CF4MRS (GenBank accession number: KM488626) was previously isolated from the GI tract of farmed freshwater catfish, Clarias batrachus (Monash University Animal Ethics Committee approval no.: MARP/2012/117) (Loh et al. 2014). The strain CF4MRS was sub-cultured regularly on de Man Rogosa and Sharp agar (MRS, Difco ${ }^{\mathrm{TM}}, \mathrm{BD}$, USA). For the bioencapsulation experiment, the cell density of $L$. lactis in MRS broth (overnight culture) was adjusted to $10^{6}, 10^{7}, 10^{8}$ and $10^{9} \mathrm{CFU} \mathrm{mL} \mathrm{m}^{-1}\left(\mathrm{OD}_{540}\right)$ using $10 \mathrm{~g} \mathrm{~L}^{-1}$ autoclaved artificial seawater ( $\mathrm{pH}$ 7.5) (Instant Ocean ${ }^{\circledR}$ Sea Salt, USA). For the in vivo assay, the pathogenic Edwardsiella sp. BCRC 16703 (98\% similarity to E. anguillarum, see supplementary BCRC 16703 gene sequences) (http://www.bcrc.firdi.org.tw) was adjusted to $10^{5} \mathrm{CFU} \mathrm{mL} \mathrm{m}^{-1}$ using sterile artificial seawater.

\section{Artemia Nauplii Hatching and Pre-disinfection}

The cysts of Artemia franciscana (Great Lake Artemia, Salt Lake City, UT, USA) were exposed to UV radiation (254 nm) for pre-disinfection in a laminar flow hood for $30 \mathrm{~min}$ prior to hatching. The cysts $\left(6 \mathrm{~g} \mathrm{~L}^{-1}\right)$ were placed in a $500-\mathrm{mL}$ Artemio ${ }^{\circledR}$ set (JBL, Neuhofen, Germany) connected to an aerator and filled with sterile artificial seawater $\left(20 \mathrm{~g} \mathrm{~L}^{-1}\right.$, $\mathrm{pH}$ 7.5). Artemia cysts were incubated under continuous aeration at $26 \pm 2{ }^{\circ} \mathrm{C}$ for $20-24 \mathrm{~h}$. (Touraki et al. 2013) and a photoperiod of 12:12 h (light:dark). The newly hatched nauplii (instar I) were collected, starved for $6 \mathrm{~h}$ and subsequently surface-disinfected with $10 \mathrm{ml} \mathrm{L}^{-1}$ Ovadine ${ }^{\circledR}(10 \%$ povidone-iodine) (Syndel Laboratories Ltd., Canada) for $10 \mathrm{~min}$. The disinfected Artemia nauplii were then used for the in vivo pathogenic study.

\section{In Vivo Challenge of Artemia Nauplii with Edwardsiella sp.}

The surface-disinfected Artemia nauplii (Instar II, at approx. $28 \mathrm{~h}$ ) were transferred into 250 -mL conical flasks with a density of approx. 300 individuals per milliliter. This experiment consisted of seven treatments: positive control (nauplii with no Lactococcus lactis subsp. lactis were administered but challenged with Edwardsiella sp.), the negative control (nauplii were administrated with $10^{6} \mathrm{CFU} \mathrm{mL}{ }^{-1}$ L. lactis but without challenged with Edwardsiella sp.), blank treatment (nauplii with no L. lactis administration and without challenged with Edwardsiella sp.) and four different treatments of nauplii, each of which were administrated with $10^{6}, 10^{7}$, $10^{8}$ and $10^{9} \mathrm{CFU} \mathrm{mL} \mathrm{m}^{-1}$ L. lactis and subsequently challenged with Edwardsiella sp. 
Artemia nauplii were exposed to L. lactis for 1, 4, 8, 12 and $24 \mathrm{~h}$. After bioencapsulation, a total of 20 Artemia nauplii per replicate were transferred aseptically from the flasks into 55$\mathrm{mm}$ (in diameter) sterile Petri dishes, containing $10 \mathrm{~mL}$ of

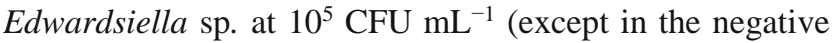
and blank treatments whereby Edwardsiella sp. was excluded). After $48 \mathrm{~h}$ of incubation, the Edwardsiella sp. suspensions were replaced with fresh suspensions at the same concentrations. A food source of autoclaved yeast Saccharomyces cerevisiae (Mauri-pan ${ }^{\circledR}$ instant yeast, Malaysia) $\left(5.6 \times 10^{7}\right.$ cells $\mathrm{mL}^{-1}$ in $10 \mathrm{~g} \mathrm{~L}^{-1}$ sterile artificial seawater, $\mathrm{pH}$ 7.5) was administered to the Artemia nauplii daily (100 $\mu \mathrm{L} \mathrm{dish}^{-1}$ ) throughout the experiment (Marques et al. 2004). Each treatment was performed in triplicate. The survival rates of the nauplii were monitored and recorded throughout the experiment until a complete mortality (100\%) was achieved in the positive control. The relative percentage of survival (RPS) was calculated based on the following formula (Amend 1981):

RPS $ð \% \mathrm{P} 1 / 41-ð M_{\mathrm{t}}=M_{\mathrm{c}} \mathrm{P} \times 100$

where $M_{\mathrm{t}}$ is mortality from treatment and $M_{\mathrm{c}}$ mortality from control. RPS values (equivalent to $\mathrm{ED}_{50}$ ) $\geq 50$ indicated a positive effect (Cunningham et al. 2010) of L. lactis against the pathogen Edwardsiella sp.

In addition, water quality was monitored throughout the experiment period for dissolved oxygen (DO), $\mathrm{pH}$, temperature, total dissolved solid (TDS), salinity and total ammonia contents (Table 1). The DO, pH, temperature, TDS and salinity were determined using an Eutech instrument (PCD 650, Thermo Fisher Scientific, Singapore), while total ammonia nitrogen $\left(\mathrm{NH}_{3}-\mathrm{N}\right)$, nitrite nitrogen $\left(\mathrm{NO}_{2}-\mathrm{N}\right)$ and nitrate nitrogen $\left(\mathrm{NO}_{3}-\mathrm{N}\right)$ were measured using a Hach colorimeter (DR890, Hach, USA) according to the Standard Methods for the Examination of Water and Wastewater (APHA 1985).

\section{Optimization of Bioencapsulation}

Firstly, new batches of Artemia nauplii were surfacedisinfected using Ovadine ${ }^{\circledR}$ and then rinsed thoroughly with autoclaved artificial seawater. Nauplii (approx. 300 nauplii $\mathrm{mL}^{-1}$ ) were transferred to $250-\mathrm{mL}$ conical flasks containing
$100 \mathrm{~mL}$ bacterial suspensions of various concentrations $\left(10^{6}\right.$, $10^{7}, 10^{8}$ and $10^{9} \mathrm{CFU} \mathrm{mL} \mathrm{mL}^{-1}$ in autoclaved artificial seawater). Artemia nauplii without treatment with $L$. lactis were used as the control. Mild aeration (filtered through $0.22-\mu \mathrm{m}$ membrane filters) was provided at the bottom of the flasks to ensure sufficient oxygenation in the Artemia culture.

To quantify the total number of L. lactis cells bioencapsulated in the nauplii, $1 \mathrm{~mL}$ of Artemia nauplii of each treatment was collected after 1, 4, 8, 12 and $24 \mathrm{~h}$ of bioencapsulation. All nauplii were washed $(5 \mathrm{~mL}$ sterile saline solution, $\mathrm{NaCl}, 0.85 \% \mathrm{w} / \mathrm{v}$ ) and collected through sterile microclothes (Calbiochem, Merck, Germany). The nauplii were then transferred to $2 \mathrm{~mL}$ sterile saline solutions and macerated using a homogenizer (LabGEN®125, Cole-Parmar, USA). Serial dilutions of the homogenized suspensions were made down to $10^{-9}$, plated $(100 \mu \mathrm{L}$ ) on nutrient agar (Badhul Haq et al. 2012) and incubated at $26 \pm 2{ }^{\circ} \mathrm{C}$ for $24-48 \mathrm{~h}$. CFU were counted to enumerate the viable bacteria that were successfully encapsulated in the Artemia nauplii (all quantification experiments were done in triplicate).

\section{Colonization of $g f p$-Transformed L. lactis in A. franciscana}

Colonization and proliferation of Lactococcus lactis subsp. lactis CF4MRS in Artemia franciscana were detected via green fluorescent protein (GFP) (Fernández de Palencia et al. 2000). The $g f p$-transformation process was firstly initiated by culturing the lactococcal cells (CF4MRS) in GM17 medium (M17 broth (Oxoid Ltd., Hampshire, UK) supplemented with $1 \%$ glucose) at $37{ }^{\circ} \mathrm{C}$ overnight. Cultures were diluted 100-fold in SGM17 medium (GM17 supplemented with $0.5 \mathrm{M}$ sucrose) containing 3\% glycine (Vivantis Technologies Sdn Bhd., Malaysia) (Holo and Nes 1989). Exponential-phase cells were grown to $0.2-0.7$ cell densities $\left(\mathrm{OD}_{600}\right)$ at $30{ }^{\circ} \mathrm{C}$. The lactococcal cells were harvested by centrifugation at $6000 \times g$ for $5 \mathrm{~min}$ at $4{ }^{\circ} \mathrm{C}$ and washed following the protocol suggested by Dornan and Collins (1990). The lactococcal cells were re-suspended in $2 \mathrm{~mL}$ of $0.22 \mu \mathrm{m}$ filtered Milli-Q water (Merck Millipore, USA), the cells were collected by centrifugation $\left(6000 \times g\right.$ for $5 \mathrm{~min}$ at $4{ }^{\circ} \mathrm{C}$ ) and the supernatant was discarded. A second wash in $1 \mathrm{~mL}$ of

Table 1 Water quality in the A. franciscana experimental flasks

\begin{tabular}{|c|c|c|c|c|c|c|c|c|}
\hline & \multirow[b]{2}{*}{$\begin{array}{l}\mathrm{DO} \\
\left(\mathrm{mg} \mathrm{L}^{-1}\right)\end{array}$} & \multirow[b]{2}{*}{$\mathrm{pH}$} & \multirow[b]{2}{*}{ Temperature $\left({ }^{\circ} \mathrm{C}\right)$} & \multicolumn{3}{|c|}{ Water quality physicochemical parameters } & \multirow[b]{2}{*}{$\mathrm{NO}_{2}-\mathrm{N}\left(\mathrm{mg} \mathrm{L}^{-1}\right)$} & \multirow[b]{2}{*}{$\mathrm{NO}_{3}-\mathrm{N}\left(\mathrm{mgL}^{-1}\right)$} \\
\hline & & & & $\begin{array}{l}\text { Salinity } \\
\text { (ppt) }\end{array}$ & $\operatorname{TDS}\left(\mathrm{mg} \mathrm{L}^{-1}\right)$ & $\mathrm{NH}_{3}-\mathrm{N}\left(\mathrm{mgL}^{-1}\right)$ & & \\
\hline Control & 3.15 & 7.4 & 22.5 & 20.0 & 15.97 & 0.80 & 0.025 & 0.02 \\
\hline Treatment & $4.09-4.30$ & $7.1-7.4$ & $22.3-22.5$ & $19.8-20.0$ & $15.49-16.00$ & $0.50-1.60$ & $0.043-0.070$ & $0.06-0.13$ \\
\hline
\end{tabular}

$\mathrm{DO}$, dissolved oxygen; $\mathrm{TDS}$, total dissolved solid; $\mathrm{NH}_{3}-\mathrm{N}$, total ammonia nitrogen; $\mathrm{NO}_{2}-\mathrm{N}$, total nitrite nitrogen; $\mathrm{NO}_{3}-\mathrm{N}$, total nitrate nitrogen 
$0.22 \mu \mathrm{m}$ filtered Milli-Q water was used. The washing steps were repeated twice to collect the cell pellets. Immediately after washing, $1 \mathrm{~mL}$ of $50 \mathrm{mmol} \mathrm{L}^{-1}$ EDTA (Sigma-Aldrich, Co., USA) was used to re-suspend the cell pellets and placed on ice for $5 \mathrm{~min}$. After incubation, cells were collected by centrifugation. The re-suspension step was repeated again with $1 \mathrm{~mL}$ of $0.22 \mu \mathrm{m}$ filtered Milli-Q water. In the final step of re-suspension, the cells were re-suspended using the same protocol by replacing Milli-Q water with $1 \mathrm{~mL}$ of $0.3 \mathrm{~mol} \mathrm{~L}^{-1}$ sucrose (Systerm ${ }^{\circledR}$, Malaysia). The lactococcal cells were then collected by centrifugation.

Prior to electrotransformation, competent lactococcal cells were re-suspended in $0.2 \mathrm{~mL}$ of $0.3 \mathrm{~mol} \mathrm{~L}^{-1}$ sucrose. Immediately after re-suspension in sucrose, the cells were mixed with $2 \mu \mathrm{g}$ of plasmid DNA. The plasmid DNA used in this study was pLS1GFP (KitMyGEN, Spain), a broadhost-range pMV158 replicon, which carries a tetL gene encoding a Tet $^{\mathrm{R}}$ determinant (Ruiz-Cruz et al. 2010), ermAM gene encoding an $\mathrm{Erm}^{\mathrm{R}}$ determinant (Ruiz-Masó et al. 2012) and the gfp gene (Fernández de Palencia et al. 2000). Cell suspensions $(100 \mu \mathrm{L})$ were transferred into a pre-chilled disposable electroporation cuvette (Bio-Rad Laboratories Inc., USA) (2-mm electrode gap) and subjected to a single pulse $\left[2.5 \mathrm{kV}\left(E=12.4 \mathrm{kV} \mathrm{cm}^{-1}\right), 200 \Omega\right.$ and $25 \mu \mathrm{F}$ corresponding to pulse length of $4.6 \mathrm{~ms}$ ] using a Gene Pulser (Xcell ${ }^{\mathrm{TM}}$,Bio-Rad Laboratories Inc., USA). Immediately after discharge, the cell suspensions were transferred to $1 \mathrm{~mL}$ of ice-cooled MRS broth (supplemented with $5 \mu \mathrm{g} \mathrm{mL}^{-1}$ erythromycin) and placed on ice for $5 \mathrm{~min}$. Cell suspensions were incubated at $37{ }^{\circ} \mathrm{C}$ for $2 \mathrm{~h}$ and $100 \mu \mathrm{L}$ was plated on MRS agars (supplemented with $5 \mu \mathrm{g} \mathrm{mL}^{-1}$ erythromycin) for the selection of erythromycin-resistant transformants. The plates were incubated for 4 to 5 days at $30{ }^{\circ} \mathrm{C}$ and colonies were inoculated onto fresh MRS agars.

To detect $g f p$-transformed L. lactis in A. franciscana, Artemia cysts were surface-disinfected and followed by the hatching process as described previously (BArtemia Nauplii Hatching and Pre-disinfection^ ${ }^{\wedge}$ section). Artemia nauplii were transferred to a conical flask containing $200 \mathrm{~mL}$ of $g f p$-transformed L. lactis bacterial suspension $\left(10^{8}-10^{9} \mathrm{CFU} \mathrm{mL}^{-1}\right)$ and mild aeration was provided during the experiment. After 6 and $12 \mathrm{~h}$ of bioencapsulation, 10-15 nauplii were collected using a Pasteur pipette and transferred into Petri dishes containing $10 \mathrm{~mL}$ sterile PBS (PBS containing $10 \mathrm{~g} \mathrm{~L}^{-1}$ Instant Ocean ${ }^{\circledR}$ Sea Salt). The nauplii were observed under a fluorescence microscope (Olympus BX43, Olympus Co., Japan) equipped with an excitation Standard FITC set, a DP26 digital camera system and UIS2 optical components, for colonization of the $g f p$-transformed L. lactis. GFP fluorescence was detected by exposing the Artemia to ultraviolet light at a wavelength of 450-490 nm. The images were captured using a DP26 digital camera system.

\section{Statistical Analysis}

The data were analyzed for normality and homogeneity of variance. For the data in percentage values, they were transformed to a square root value prior to the analysis using ANOVA (Tukey test). Significant values were accepted at $P$ value $<0.05$. Statistical analysis was performed using the Statistical Package for the Social Sciences (SPSS) Version 20.

\section{Results}

Generally, Lactococcus lactis subsp. lactis CF4MRS at $10^{8} \mathrm{CFU} \mathrm{mL}^{-1}$ and bioencapsulated for $8 \mathrm{~h}$ to Artemia franciscana nauplii showed the highest protective effect against Edwardsiella sp. infection. The survival of both A. franciscana groups in the negative control and those ad-

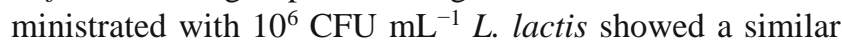
trend with no significant differences $(P>0.05)$ found between the blank treatment and positive control (Fig. 1a). Application of different $L$. lactis cell densities resulted in a slight increase in the relative percentage of survival (RPS) compared to the positive control (Table 2). No significant difference was found in the survival of $A$. franciscana in the negative and blank treatments $(P>0.05)$ (Fig. 2a). However, all L. lactis densities $\left(10^{6}-10^{9} \mathrm{CFU} \mathrm{mL}^{-1}\right)$ showed a significant reduction $(P$ $<0.05$ ) in the survival rate of $A$. franciscana (Fig. 2a) regardless of the bioencapsulation duration, when compared to the positive control. A lower survival was noticed when A. franciscana administrated with $10^{6} \mathrm{CFU} \mathrm{mL} \mathrm{m}^{-1}$ L. lactis for $4 \mathrm{~h}$ (Fig. 1b). However, no significant difference was observed in the survival of $A$. franciscana administrated with $10^{7}-10^{9} \mathrm{CFU} \mathrm{mL} \mathrm{mL}^{-1}$ L. lactis $(P>0.05)$ (Fig. 2a). The RPS was recorded in the range of 31.7-48.3 within 4-12 h (Table 2). The survival of A. franciscana $\left(10^{8} \mathrm{CFU} \mathrm{mL} \mathrm{mL}^{-1}\right.$ L. lactis; $8 \mathrm{~h}$ ) was higher than those fed with $10^{9} \mathrm{CFU} \mathrm{mL} \mathrm{m}^{-1}$ L. lactis (Fig. 1c). In terms of RPS, A. franciscana administrated with $10^{8} \mathrm{CFU} \mathrm{mL} \mathrm{m}^{-1} \mathrm{~L}$. lactis showed the highest protective effect against Edwardsiella sp. (RPS $=50.0)$ (Table 2). Bioencapsulated Artemia with $10^{8} \mathrm{CFU} \mathrm{mL} \mathrm{mL}^{-1}$ L. lactis for 8 -h duration showed $50 \%$ survival rate which was similar to those found in the negative control (nauplii not challenged with Edwardsiella sp.) (Fig. 2a). This trend, however, did not occur during the extended period of bioencapsulation $(t=12$ and $24 \mathrm{~h})$. The survival did not significantly differ $(P>0.05)$ in the $A$. franciscana treated with different $L$. lactis cell densities. In terms of bioencapsulation time, no significant difference $(P>0.05)$ was observed among the duration and cell density, except for the negative and blank treatments (Fig. 2b).

The total estimated bacteria bioencapsulated in the A. franciscana increased relatively to the bacterial density and bioencapsulation time (Fig. 3). Only a cell density at $10^{9} \mathrm{CFU} \mathrm{mL}^{-1}$ showed a significant difference $(P>0.05)$ 
A

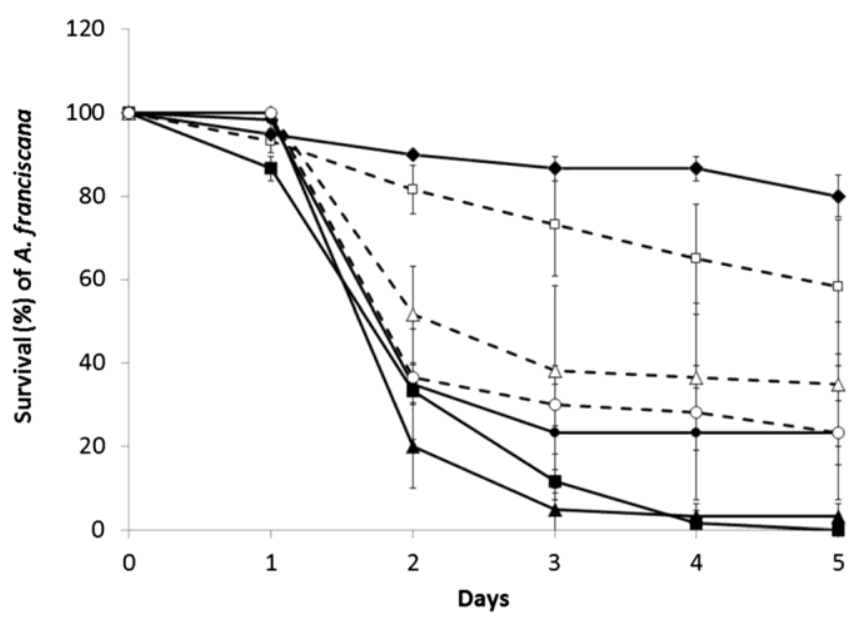

C
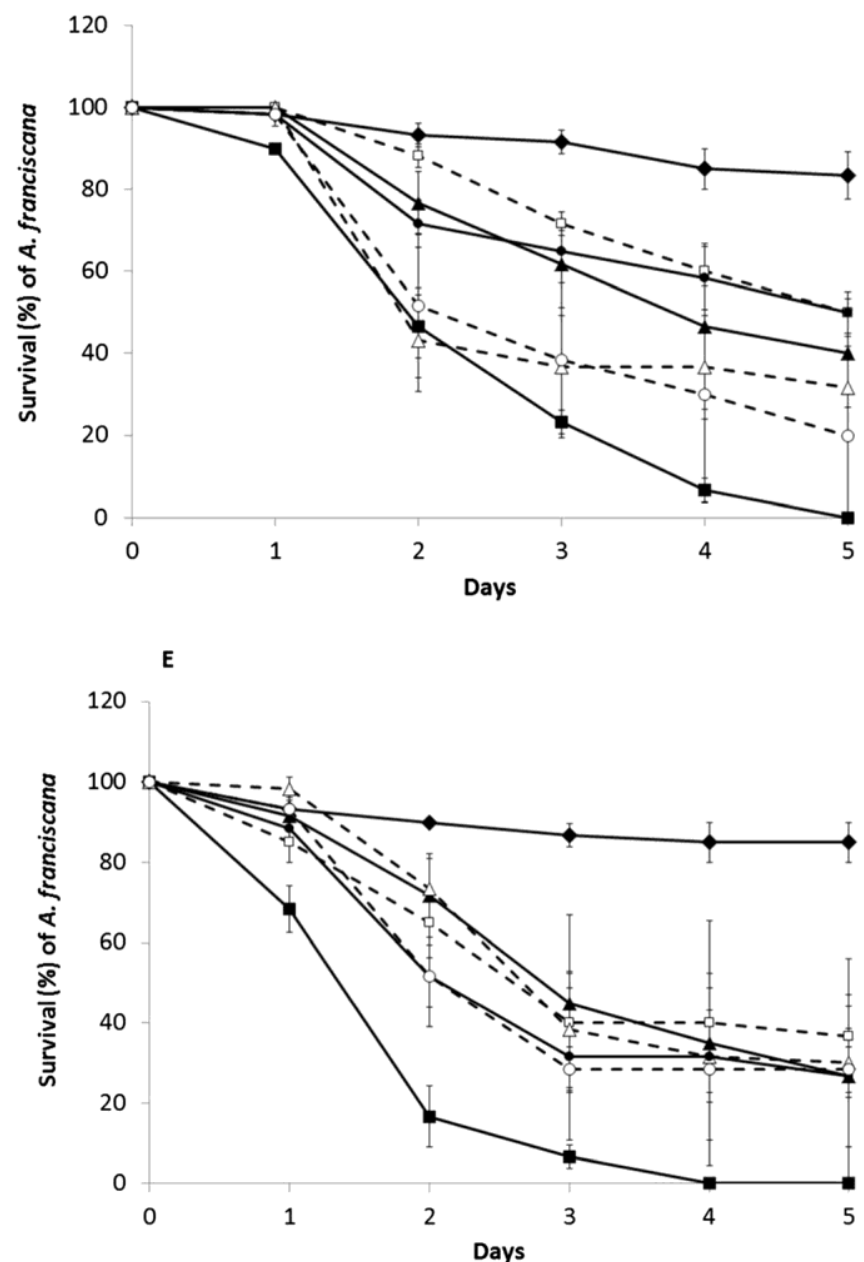

Fig. 1 Survival of A. franciscana administrated with or without L. lactis for a $1 \mathrm{~h}, \mathrm{~b} 4 \mathrm{~h}, \mathrm{c} 8 \mathrm{~h}, \mathrm{~d} 12 \mathrm{~h}$, and e $24 \mathrm{~h}$ in the presence of Edwardsiella sp. (in vivo challenging) or without Edwardsiella sp. $\longrightarrow$ positive control, $-\square$ - negative control, $\longrightarrow$ blank control, $\longrightarrow$ - nauplii

compared to the lower bacterial densities and the control (without bioencapsulation). The total number of bacteria in the A. franciscana increased tenfold when compared to those in
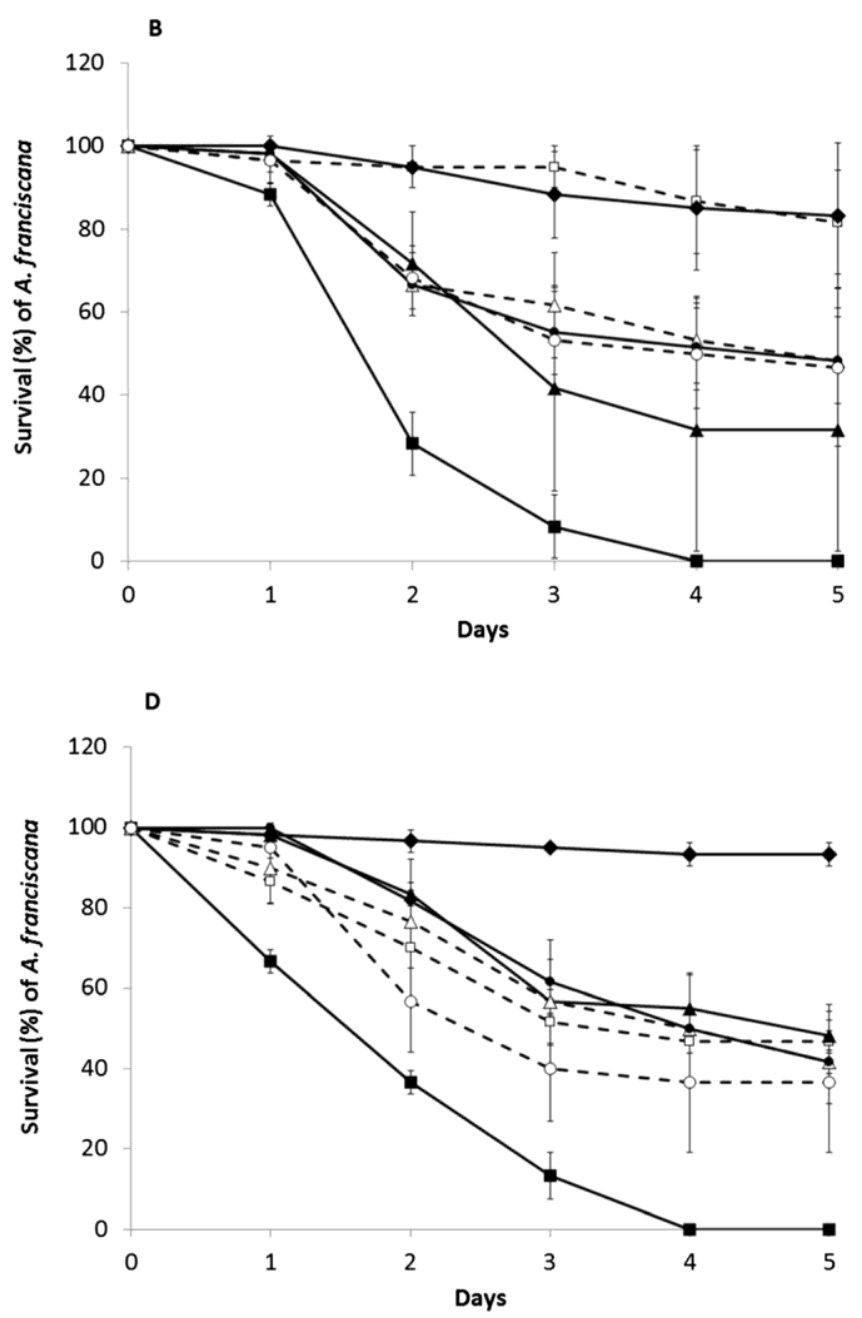

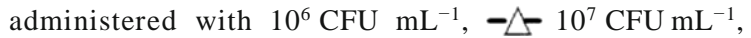
$10^{8} \mathrm{CFU} \mathrm{mL} \mathrm{m}^{-1}$, and $-\mathrm{O}-10^{9} \mathrm{CFU} \mathrm{mL}^{-1}$ of L. lactis. Vertical error bars indicate standard deviation of means

the control $\left(1.7 \times 10^{6} \mathrm{CFU} \mathrm{mL} \mathrm{m}^{-1}\right)$, resulting in an average of $5.2 \times 10^{6} \mathrm{CFU} \mathrm{mL} \mathrm{mL}^{-1}$ of bacteria when administrated with $10^{9} \mathrm{CFU} \mathrm{mL} \mathrm{mL}^{-1}$ of $L$. lactis in the first hour. The total estimated 
Table2 Mortality and relative percentage survival (RPS) of L. lactis subsp. lactis-bioencapsulated A. franciscana after challenged with Edwardsiella sp.

Lactococcus lactis subsp. lactis CF4MRS concentration

\begin{tabular}{|c|c|c|c|c|c|c|c|c|c|c|}
\hline \multirow[b]{2}{*}{ Time (h) } & \multicolumn{2}{|l|}{ Control $^{\mathrm{a}}$} & \multicolumn{2}{|l|}{$10^{6} \mathrm{CFU} \mathrm{mL}$} & \multicolumn{2}{|l|}{$10^{7} \mathrm{CFU} \mathrm{mL} \mathrm{m}^{-1}$} & \multicolumn{2}{|l|}{$10^{8} \mathrm{CFU} \mathrm{mL}^{-1}$} & \multicolumn{2}{|l|}{$10^{9} \mathrm{CFU} \mathrm{mL}^{-1}$} \\
\hline & Mortality (\%) & RPS & Mortality (\%) & RPS & Mortality (\%) & RPS & Mortality (\%) & RPS & Mortality (\%) & RPS \\
\hline 1 & 100 & - & 97 & 3.3 & 65 & 35.0 & 77 & 23.3 & 77 & 23.3 \\
\hline 4 & 100 & - & 68 & 31.7 & 52 & 48.3 & 52 & 48.3 & 53 & 46.7 \\
\hline 8 & 100 & - & 60 & 40.0 & 68 & 31.7 & 50 & 50.0 & 80 & 20.0 \\
\hline 12 & 100 & - & 52 & 48.3 & 58 & 41.7 & 58 & 41.7 & 63 & 36.7 \\
\hline 24 & 100 & - & 73 & 26.7 & 70 & 30.0 & 73 & 26.7 & 72 & 28.3 \\
\hline
\end{tabular}

${ }^{\mathrm{a}}$ Artemia did not receive administration of Lactococcus lactis subsp. lactis and are challenged with Edwardsiella sp.

Fig. 2 Survival of A. franciscana at the end of experiment (5 days). a Survival rate at different bioencapsulation durations. $b$ Survival rate at different treatments. Mean values with same letters within groups are not significantly different $\left(\mathrm{HSD}_{0.05}\right)$. Vertical bars indicate standard deviation of means

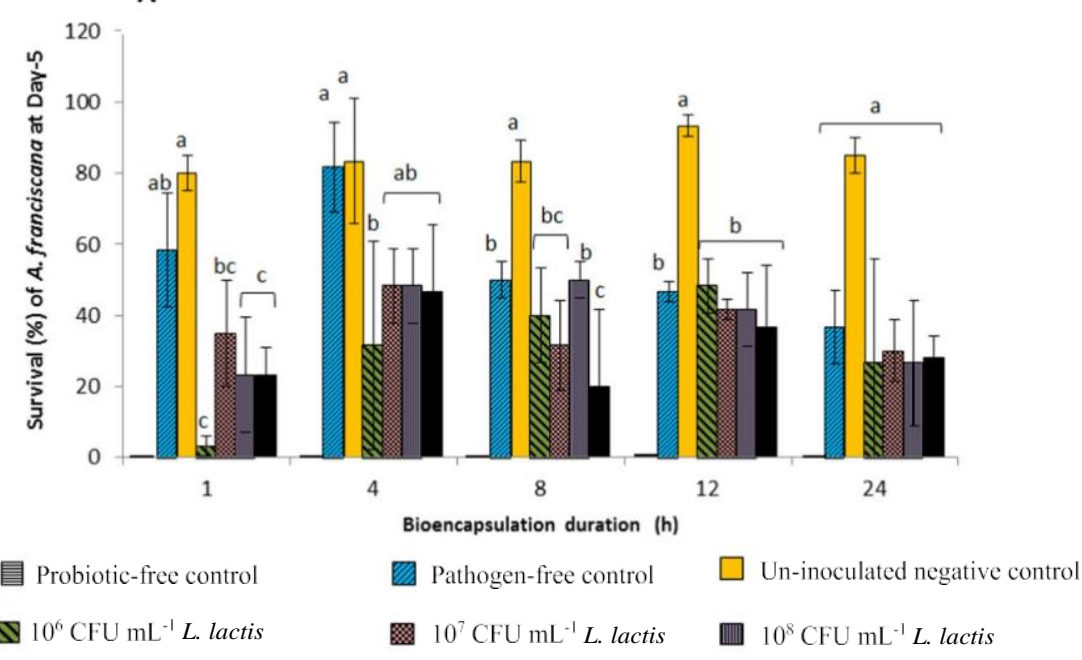

$10^{9} \mathrm{CFU} \mathrm{mL}^{-1}$ L. lactis

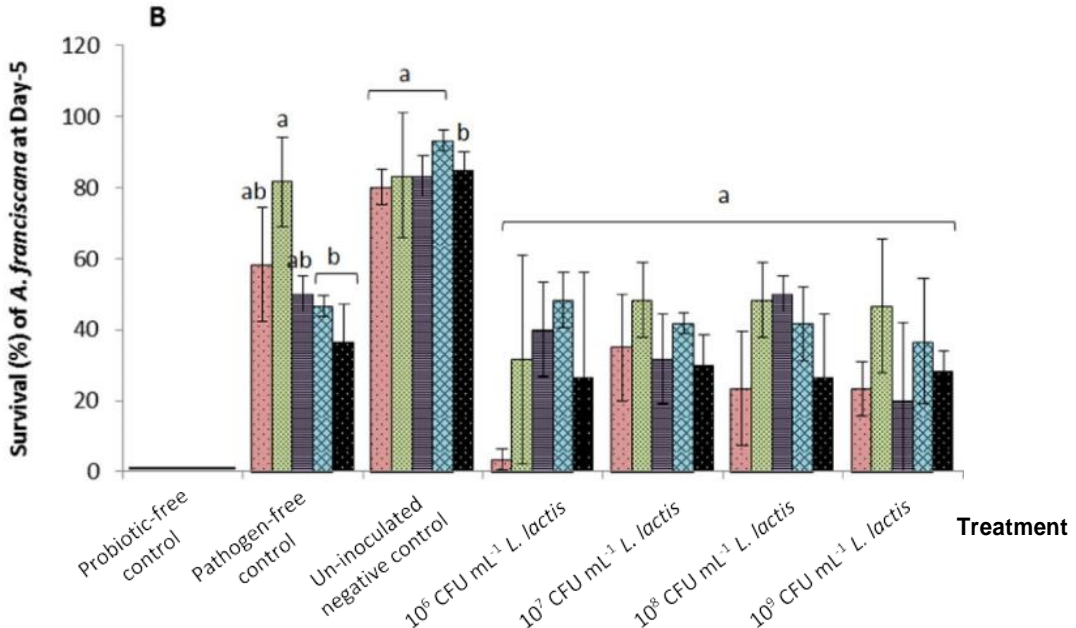

1-hour

읐 4hour

8-hour

12-hour

24-hour 
Fig. 3 Estimation of total bacteria bioencapsulatedin A. franciscana at $1,4,8,12$, and $24 \mathrm{~h}$, introduced by the initial cell densities of L. lactococcus subsp. lactis at $10^{6}, 10^{7}, 10^{8}$, and $10^{9} \mathrm{CFU} \mathrm{mL} \mathrm{m}^{-1}$. Mean values with same letters within groups are not significantly different $\left(\mathrm{HSD}_{0.05}\right)$. Vertical bars indicate standard deviation of means

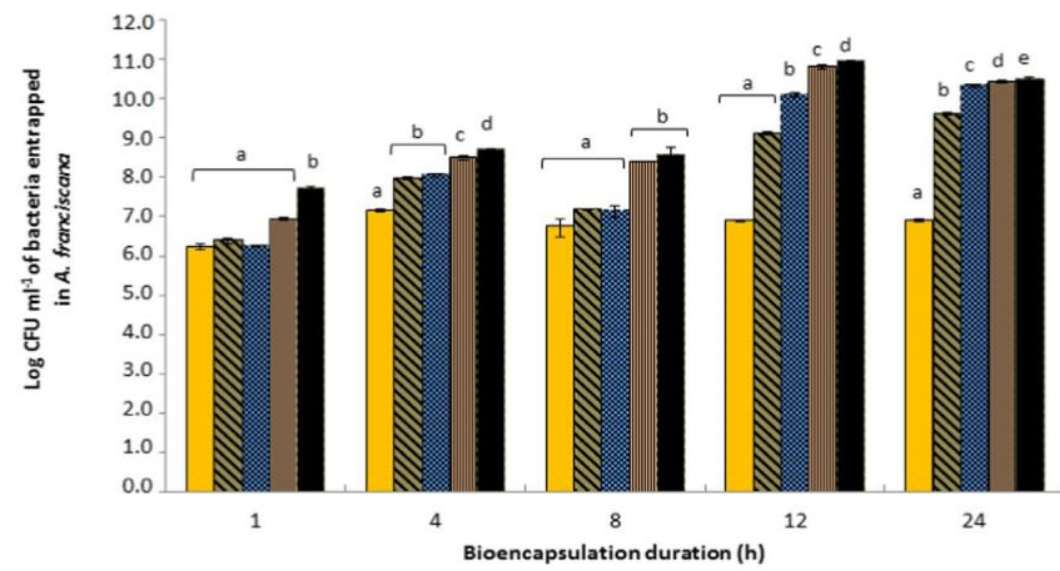

Control (no L. lactis) $\mathbf{\nabla} 10^{6} \mathrm{CFU} \mathrm{mL}^{-1}$ L. lactis
$10^{7} \mathrm{CFU} \mathrm{mL}^{-1}$ L. lactis count of bacteria also increased tenfold when exposed to $10^{8}$ and

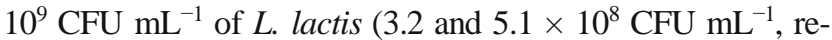
spectively) for $4 \mathrm{~h}$ while the bacterial count in the control was only $1.4 \times 10^{7} \mathrm{CFU} \mathrm{mL}{ }^{-1}$. When the bioencapsulation time was extended to $8 \mathrm{~h}$, a remarkable change was observed, whereby the total bacterial count increased to 20 -fold at $10^{8}\left(2.4 \times 10^{8}\right)$ and $10^{9} \mathrm{CFU} \mathrm{mL}^{-1}\left(3.9 \times 10^{8} \mathrm{CFU} \mathrm{mL}^{-1}\right)$ L. lactis, respectively. The total bacterial count continued to increase up to 40 -fold compared to the control when the time was extended to 12 and $24 \mathrm{~h}$.
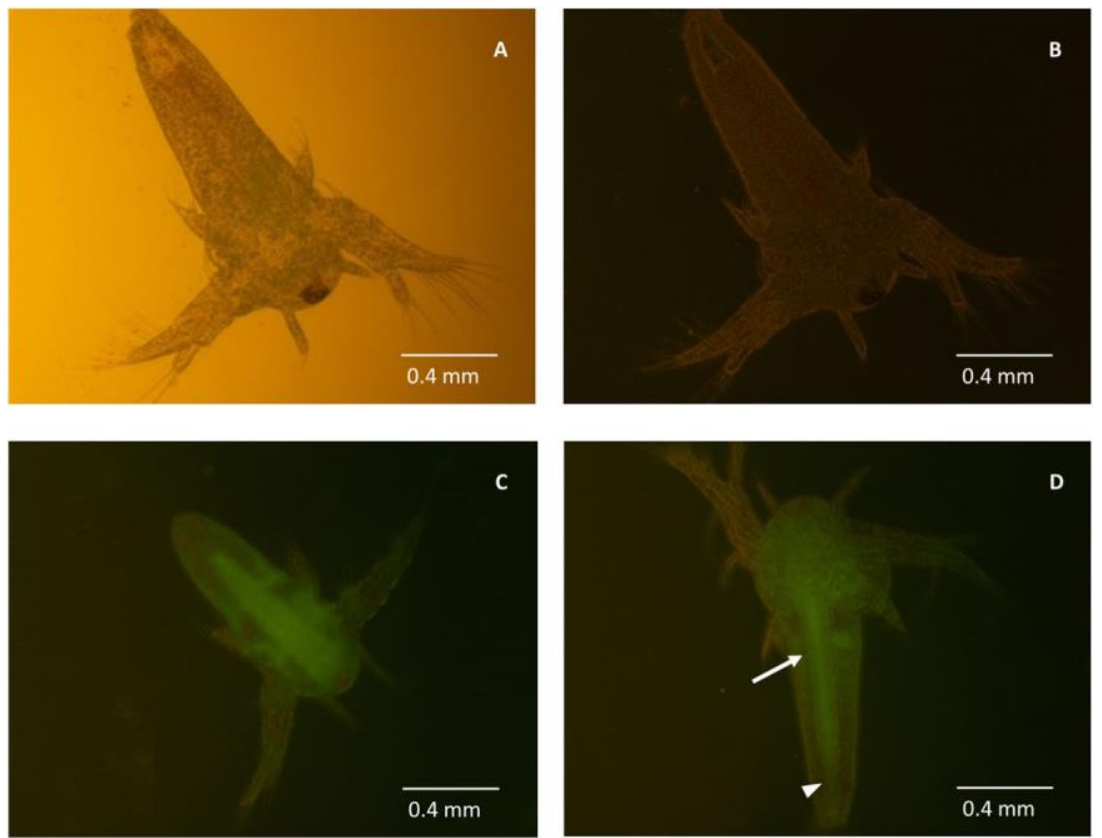

Fig. 4 Visualization of $g f p$-transformed L. lactic subsp. lactis in A. franciscana: a wild-type A. franciscana without administrated to L. lactis (control) under bright-field-view microscopy; b wild-type control A. franciscana under dark-field-view microcopy; c instar II of A. franciscana administrated to $10^{8}-10^{9} \mathrm{CFU} \mathrm{mL} \mathrm{m}^{-1}$ gfp-transformed
In terms of bacterial uptake, proliferation and colonization, control Artemia did not have a fluorescent signal after ultraviolet light exposure (Fig. 4a, b). In contrast, green fluorescent spots were detected on the external trunk surfaces, including a pair of locomotion antennules of the instar after being administered with $g f p$-transformed $L$. lactis for $6 \mathrm{~h}$. The fluorescence intensity was particularly intense in the areas of the esophagus up to the mid-gut (Fig. 4c), suggesting that the bacterial intake could have commenced at the stages of instar II to III.

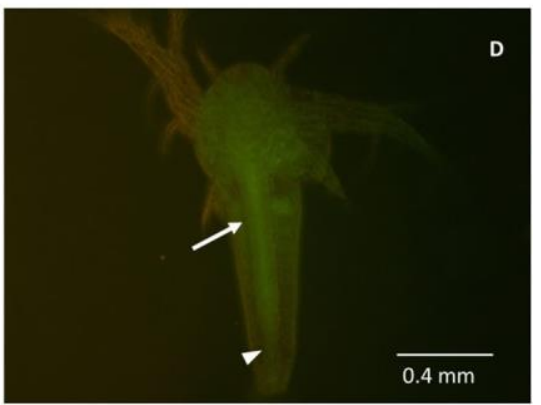

L. lactic for $6 \mathrm{~h}$; d nauplii of $A$. franciscana administrated to the same concentration of $g f p$-transformed L. lactic for $12 \mathrm{~h}$. Putative adhesion of bacteria (c, d) in the mid-gut (indicated with arrows) and hindgut areas (arrow heads) were viewed under dark-field-view microcopy with exposure of ultraviolet light in the range of $450-490 \mathrm{~nm}$ 
Bacterial proliferation in gut epithelial cells was observed in the nauplii (12 h). Bacterial cells were mostly confined to the GI tract and colonized mainly to the anterior parts of the body surface (Fig. 4d). In comparison with instar, the bacteria in the nauplii colonized the entire digestive tract towards the hindgut.

\section{Discussion}

In this present study, Artemia franciscana administrated with Lactococcus lactic subsp. lactis CF4MRS showed a significant survivorship after challenged with Edwardsiella sp. RPS showed $A$. franciscana administrated with $10^{8} \mathrm{CFU} \mathrm{mL}^{-1}$ for 8-h bioencapsulation offered the best protection against Edwardsiella sp. (Table 2). However, the cell density of

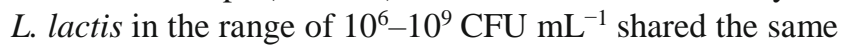
protection as the survival of $A$. franciscana in the pathogenic challenging de facto. This result is in agreement with Touraki et al. (2013) where the authors found no significant effect on the survival of $A$. franciscana regardless of the dosage concentration of L. lactis subsp. lactis used in Vibrio anguillarum challenge study. And yet, some studies suggest that a probiotic concentration of at least $10^{8} \mathrm{CFU} \mathrm{mL}^{-1}$ is required to protect Artemia from Vibrio spp. infection (Lamari et al. 2013). When L. lactis is used as a prophylactic treatment for sea bass to prevent against vibriosis infection, the application dosage of the probiotic is suggested to be within the range of $10^{6}-$ $10^{7} \mathrm{CFU} \mathrm{mL}{ }^{-1}$ (Touraki et al. 2013). There are nu- merous studies on the application of lactic acid bacteria in fish and shrimp cultures; all of these showed promising results in disease protection. However, it is worth men- tioning that when L. lactis was supplied solely in live feed cultivation (Artemia in our case), without a pathogen, a noticeable mortality rate of Artemia was observed in the culture (Figs. 1 and 2); this is presumably attributed to starvation as no food was provided during the bioencapsulation process.

The administration of the probiotic before the first exogenous feeding can facilitate the establishment of beneficial bacteria through their colonization in the digestive tract (Motlagh et al. 2012). Bacterial colonization in the digestive tract relies mainly on the number of bacteria being introduced and its proliferation capability in the intestinal system (Ziaei-Nejad et al. 2006). Therefore, it is crucial to understand the effects of bacterial density and incubation time, and the interaction between these two factors with/without exposure to the pathogen. The total bacterial count entrapped in A. franciscana exposed to L. lactis at $10^{8}-$ $10^{9} \mathrm{CFU} \mathrm{mL} \mathrm{m}^{-1}$ showed a significant increment at prolonged bioencapsulation duration i.e. $>4$ h. Although Artemia cysts were surface-sterilized with povidone-iodine (Ovadine ${ }^{\circledR}$ ), some bacteria were still observable on the surface of A. franciscana in the control group. This presumably could be due to the presence of natural microflora in the hatched nauplii. According to Sahul Hameed (1993) and Phatarpekar et al. (2002), the crustacean Penaeus indicus and Macrobrachium rosenbergii larvae were found to be dominated by some bacteria species upon hatching, even though their egg homogenates were sterile (Colorni 1985). This might be primarily due to the natural microflora present in the digestive tract of the animals (Colorni 1985). Our results indicate that bioencapsulation using L. lactis at $10^{8}$ $10^{9} \mathrm{CFU} \mathrm{mL} \mathrm{mL}^{-1}$ could improve the total bacterial count in A. franciscana from 10- to 40-fold compared to those in the control. The recovery of the probiotic was relatively higher than that of other strains such as Bacillus subtilis and B. licheniformis, where only $10^{4}-10^{6} \mathrm{CFU} \mathrm{mL}^{-1}$ of the total bacterial count were recovered from bioencapsulated A. urmiana (Motlagh et al. 2012). The higher CFU mL $\mathrm{m}^{-1}$ presented in this study could be due to different probiotic strains, Artemia species and also the enumeration technique used as well.

In terms of bacterial uptake, proliferation and colonization, results showed that L. lactis mainly localized at the external trunk surfaces and in the digestive tracts of the zooplankton (Artemia nauplii). Probiotic adhesion capacity on the intestinal tract is a fundamental prerequisite in probiotic treatments to transient colonization, while others include antagonistic activity against invasive pathogens and the stimulation of innate immunity (Lauzon et al. 2008; Fjellheim et al. 2010; Motlagh et al. 2012). The adhesion capacity of a putative probiotic can be assessed through different approaches such as a cell line attachment assay. Lauzon et al. (2008) showed that the adhesion capacity of an actinobacteria group of probiotic which was isolated from salmon was only prominent in certain cell lines. Lactic acid-producing bacteria, especially Carnobacterium divergens V41, do not adhere to Epithelioma papulosum cyprini (EPC) cell lines. The authors suggested that the evaluation of adhesion capacity solely based on cell lines could be a limitation. Furthermore, no cell line has yet been established for freshwater fish (Lauzon et al. 2008). Our study showed that the $g f p$-transformed L. lactis subsp. lactis has shown a significant capability of proliferation and colonization of the probiotic. More importantly, it provides a real-time observation for the presence of bacteria on the surfaces and in the digestive tract of A. franciscana. To our knowledge, this is the first report on gut colonization and proliferation in the GI of Artemia through the employment of $g f p$.

In conclusion, our study suggests that bioencapsulated Artemia with L. lactis subsp. lactis CF4MRS at $10^{8} \mathrm{CFU} \mathrm{mL}^{-1}$ for $8 \mathrm{~h}$ could effectively increase the survival rate of live feed up to $50 \%$ against Edwardsiella sp. infection. Extensive colonization of this bacterium on Artemia also confirms the potential use of this probiotic in larviculture. 
Acknowledgements The authors would like to express their gratitude to Dr. Paloma López (Centro de Investigaciones Biológicas, CSIC, Madrid, Spain) for her technical guidance in $g f p$ gene insertion and bacterial electrotransformation. Special thanks to Professor Sharr Azni Harmin (Universiti Selangor, Malaysia) and Associate Professor Yau Yan Lim (Monash University, Malaysia) for technical consultation.

Funding Information This study was funded by the Higher Degree Research (HDR) grant from Monash University, Malaysian campus.

\section{References}

Amend DF (1981) Potency testing of fish vaccines. Dev Biol Stand 49: $447-454$

Andani HRR, Tukmechi A, Meshkini S, Sheikhzadeh N (2012) Antagonistic activity of two potential probiotic bacteria from fish intestines and investigation of their effects on growth performance and immune response in rainbow trout (Oncorhynchus mykiss). J Appl Ichthyol 2012:1-7

APHA (1985) Standard methods for the examination of water and wastewater, 16th edn. American Public Health Association, Washington, D.C.

Badhul Haq MA, Vijayasanthi P, Vignesh R, Shalini R, Somnath Chakraborty R, Rajaram R (2012) Effect of probiotics against marine pathogenic bacteria on Artemia franciscana. J Pharmacol Sci 2(4):38-43

Bullock GL, Herman RL (1985) Edwardsiella infections of fishes. US Fish and Wildlife Service, University of Nebraska-Lincoln, pp 6

Chang CI, Liu WY (2002) An evaluation of two probiotic bacterial strains, Enterococcus faecium SF 68 and Bacillus toyoi, for reducing edwardsiellosis in cultured Europeaneel,Anguilla anguilla L.JFish Dis 25:311-315

Colorni A (1985) A study on the bacterial flora of giant prawn, Macrobrachium rosenbergii, larvae fed with Artemia salina nauplii. Aquaculture 49:1-10

Cunningham F, Lees P, Elliott J (2010) In: F. Cunningham et al (Eds) Comparative and veterinary pharmacology. Handbook of experimental pharmacology. Springer-Verlag Berlin, Heidelberg

Dornan S, Collins MA (1990) High efficiency electroporation of Lactococcus lactis subsp. lactis LM0230. Letter Appl Microbiol 11:62-64

FAO (Food and Agriculture Organization of the United Nations) \& WHO (World Health Organization) (2001) Evaluation of health and nutritional properties of powder milk and live lactic acid bacteria. Food and Agriculture Organization of the United Nations and World Health Organization expert consultation report, FAO, Rome, Italy

Fernández de Palencia P, Nieto C, Acebo P,Espinosa M, López P (2000) Expression of green fluorescent protein in Lactococcus lactis. FEMS Microbiol Lett 183:229-234

Fjellheim AJ, Klinkenberg G, Skjermo J, Aasen IM, Vadstein O (2010) Selection of candidate probionts by two different screening strategies from Atlantic cod (Gadus morhua L.) larvae. Vet Microbiol 144:153-159

Hai NV, Buller N, Fotedar R (2010) Encapsulation capacity of Artemia nauplii with customized probiotics for use in cultivation of western king prawns (Penaeus latisulcatus Kishinouye, 1968). Aquac Res 41:893-903

Harikrishnan R, Balasundaram C, Heo MS (2010) Lactobacillus sakei BK19 enriched diet enhances the immunity status and disease resistance to streptococcosis infection in kelp grouper, Epinephelus bruneus. Fish Shellfish Immun 29:1037-1043

Holo H, Nes IF (1989) High-frequency transformation, by electroporation, of Lactococcus lactis subsp. cremoris grown with glycine in osmotically stabilized media. Appl Environ Microbiol 55(12):3119133
Kim KW, Wang X, Choi SM, Park GJ, Koo JW, Bai SC (2003) No synergistic effects by the dietary supplementation of ascorbic acid, a-tocopheryl acetate and selenium on the growth performance and challenge test of Edwardsiella tarda in fingerling Nile tilapia, Oreochromis niloticus L. Aquac Res 34:1053-1058

Lamari F, Sadok K, Bakhrouf A, Gatesoupe FJ (2013) Selection of lactic acid bacteria as candidate probiotics and in vivo test on Artemia nauplii. Aquacult Int 22:699-708

Lauzon HL, Gudmundsdottir S, Pedersen MH, Budde BB, Gudmundsdottir BK (2008) Isolation of putative probionts from cod rearing environment. Vet Microbiol 132:328-339

Loh JY, Lim YY, Harmin SA, Ting ASY (2014) In vitro assessment on intestinal microflora from commonly farmed fishes for control of the fish pathogen Edwardsiella tarda. Turk J Vet Anim Sci 38:257-263

Loh JY, Ting ASY (2016) Effects of potential probiotic Lactococcus lactis subsp. lactis on digestive enzymatic activities of live feed Artemia franciscana. Aquacult Int 24:1341-1351

Mainous ME, Smith SA, Kuhn DD (2010) Effect of common aquaculture chemicals against Edwardsiella ictaluri and E. tarda. J Aquat Anim Health 22:224-228

Marques A, François JM, Dhont J, Bossier P, Sorgeloos P (2004) Influence of yeast quality on performance of gnotobiotically grown Artemia. J Exp Mar Biol Ecol 310:247-264

Méndez-Hermida F, Gómez-Couso H, Ares-Mazás E (2007) Possible involvement of Artemia as live diet in the transmission of cryptosporidiosis in cultured fish. Parasitol Res 101(3):823-827

Mohanty BR, Sahoo PK (2007) Edwardsiellosis in fish: a brief review. J Biosci 32(7):1331-1344

Motlagh HRZ, Farhangi M, Rafiee G, Noori F (2012) Modulating gut microbiota and digestive enzyme activities of Artemia urmiana by administration of different levels of Bacillus subtilis and Bacillus licheniformis. Aquacult Inter 20:693-705

Padros F,Zarza C, Dopazo L, Cuadrado M, Crespo S (2006) Pathology of Edwardsiella tarda infection in turbot, Scophthalmus maximus (L.) J Fish Dis 29:87-94

Phatarpekar PV, Kenkre VD, Sreepada RA, Desai UM, Achuthankutty CT (2002) Bacterial flora associated with larval rearing of the giant freshwater prawn, Macrobrachium rosenbergii. Aquaculture 203: 279-291

Ruiz-Cruz S, Solano-Collado V,Espinosa M, Bravo A (2010) Novel plasmid-based genetic tools for the study of promoters and terminators in Streptococcus pneumoniae and Enterococcus faecalis. J Microbiol Methods 83:156 163

Ruiz-Masó JA, López-Anguilar C, Nieto C, Sanz M, Burón P, Espinosa M, del Solar G (2012) Construction of a plasmid vector based on the pMV158 replicon for cloning and inducible gene expression in Streptococcus pneumonia. Plasmid 67:53-59

Sahul Hameed AS (1993) A study of the aerobic heterotrophic bacterial flora of hatchery-reared eggs, larvae and post-larvae of Penaeus indicus. Aquaculture 117:195-204

Sahoo PK, Mukherjee SC, Sahoo SK (1998) Aeromonas hydrophila versus Edwardsiella tarda: A pathoanatomical study in Clarias batrachus. Aquaculture 6:57-66

Saravanan K, Nilavan SE, Sudhagar SA, Naveenchandru V (2013) Diseases of mariculture finfish species: a review. Isr J Aquacult Bamidgeh. IJA_64.2012.831

Situmorang ML, Dierckens K, Mlingi FT, Van Delsen B, Bossier P (2014) Development of a bacterial challenge test for gnotobiotic Nile tilapia Oreochromis niloticus larvae. Dis Aquat Org 109:23-34

Sivakumar VK, Sarathi M, Venkatesan C, Sivaraj A, Sahul Hameed AS (2009) Experimental exposure of Artemia to Hepatopancreatic parvo-like virus and subsequent transmission to post-larvae of Penaeus monodon. J Invertebr Pathol 102:191-195

Touraki M, Karamanlidou G, Koziotis M, Christidis I (2013) Antibacterial effect of Lactococcus lactis subsp. lactis on Artemia 
fransciscana and Dicentrarchus labrax larvae against the fish pathogen Vibrio anguillarum. Aquacult Inter 21:481-495

Villamil L, Figueras A, Planas M, Novoa B (2010) Pediococcus acidilactici in the culture of turbot (Psetta maxima) larvae: administration pathways. Aquaculture 307:83-88

Zheng D, Mai K, Liu S, Cao L, Liufu Z, Xu W, Tan B, Zhang W (2004) Effect of temperature and salinity on virulence of Edwardsiella tarda to Japanese flounder, Paralichthys olivaceus (Temminck et Schlegel). Aquac Res 35:494-500

Ziaei-Nejad S, Rezaei MH, Takami GA, Lovett DL, Mirvaghefi AR, Shakouri M (2006) The effect of Bacillus spp. bacteria used as probiotics on digestive enzyme activitiy, survival and growth in the Indian white shrimp (Fenneropenaeus indicus). Aquaculture 252:516-524 